sented, others have rare earthwork survivals. Expanses of field system now represent a great unknown within and below which may lurk earlier features. The density of, for example, flint scatters among Celtic fields in Wessex (Richards 1990) and the new sites currently emerging from the levelled clay-land ridge-andfurrow emphasize that the present distribution of archaeological features reflects only one layer (or bits of many layers?) of the cake.

If, as this note suggests, one property of earthwork sites is their protecting of earlier features, it becomes important to schedule, or regulate arable use on, all earthworks whatever their form, rarity, or location. This action would leapfrog some costly current programmes, although these may still offer useful comment on known levelled sites. By their very nature, levelled sites are already partially damaged whereas any earthwork offers potentially more information. If archaeology needs a worthwhile millennium project, preservation of our remaining earthworks surely must rank high.

Acknowledgements. I thank Chris Cox and David Hall for comments on an earlier version of this note. The former (as usual) for making me remove the rude bits, the latter (as usual) for advice on medieval fields and for allowing re-use of his 1972 drawing.
References

ALLEN. G.W.G. 1984. Discovery from the air. Aerial Archaeology 10.

HaLl, D.N. 1972. Modern surveys of medieval field systems, Bedfordshire Archaeological Journal 7: 53-66.

PALMER, R. 1994. Stowe Farm, West Deeping, Lincolnshire (centred TF100110), aerial photographic assessment. Air Photo Services Report R53. (Copy held by Cambridgeshire SMR.)

PHILliPs, C.W. (ed). 1970. The Fenland in Roman times. London: Royal Gengraphical Society. RGS Research Series 5.

PRYOR, F.M.M. \& C.A.I. FRIiNCH. 1985. The Fenland project 1 : archaeology and environment in the lower Welland Valley, East Anglian Archaeology 27.

RCHME. 1960. A matter of time: an archaeological survev of the river gravels of England. London: HMSO.

Richardos, J. 1990. The Stonehenge Environs Project. London: English Heritage. Archaeological Report 16

Simpson, W.G., D.A. GuRNeY, J. NEve \& F.M.M. Pryor. 1993 The Fenland Project 7: excavations in Peterborough and the lower Welland Valley 1960-1969, East Anglian Archaeology 61

\title{
Repatriation, power relations and the politics of the past
}

\author{
TAMARA L. BRAY*
}

\begin{abstract}
Museums across the USA are busy carrying out their new obligations under NAGPRA, the Native American Graves Protection and Repatriation Act. There is more to the mood than some change in how human remains are curated in archaeological and anthropological collections.
\end{abstract}

In repatriation, we have a conceptual locus at which several issues of critical importance to contemporary American archaeology converge. These involve concerns about multiple interests in the past, its commodification and ownership, the instrumentality of the past and the reification of this temporal realm as a 'zone of authentification'. This short essay explores the complex linkages between repatriation and this powerful antecedent domain of 'The Past'.

In recent journal articles, symposia and workshops devoted to repatriation, discussions seem to have advanced little beyond a basic concern with compliance and implementation. While some colleagues have used repatriation as a springboard to address the need for new partnerships and greater cooperation with the Native American community (Goldstein 1992; Killion \& Bray 1994; Loring 1995; Spector 1994), it is my general impression that many are still in denial about its impact or importance and simply seek to avoid entanglement. Whether one wishes to remain on the sidelines or not, however, is no longer the issue. The dam of

\footnotetext{
* Department of Anthropology, Wayne State University, Detroit MI 48202, USA.

e-mail: TBRAY@CMS.CC.WAYNE.EDU
}

Received 24 August 1995, accopted 20 November 1995.

ANTIQUITY 70 (1996): $440-44$ 
science has been breached, so to speak, and one senses a groundswell of resolve within the Native community to follow the charter provided by recent legislation. The questions posed here are not whether we engage this issue, but how, and not whether repatriation is significant, but why.

At this juncture in the history of American archaeology, it seems we have reached the proverbial fork in the road. We are confronted with a choice of circling the wagons and attempting to consolidate our control over the archaeological past or reformulating the goals and methods of apprehending the past as a more inclusive endeavour. Continuing with a primary focus on questions about the nature and content of the archaeological record confines our understanding of the past to the boundaries of our object of study. If we wish to democratize the past rather than to colonize it, we need to expand the scope of our inquiry to include selfreflexive analysis of the concepts and categories by which we construct it.

Focusing on the interpretative aspects of the archaeological endeavour brings into clearer view the codes and categories we rely on to 'read' the archaeological record. Following Jameson (1981: 10), interpretation can be understood as an essentially allegorical act. In archaeology, interpretation involves the re-presentation of the archaeological record in terms of a particular master code, one that is most often about the story of progress. Juxtaposing the 'master codes' of archaeologists with those of other stake-holders in the past demonstrates the situated or 'local' way in which the object of study, the archaeological record, is constructed. It also highlights the 'strategies of containment' enabling the illusion that the object and its reading is somehow complete and selfsufficient. Recognizing that archaeological knowledge about the past is constructed through an interpretative process according to a culturally specific (not universal) meta-narrative about human history allows the possibility of acknowledging and respecting alternative visions of the past constructed within other cultural frameworks.

It follows from the above that a political orientation is not just supplementary to a culture historical, processual or neo-evolutionary reading of the archaeological record. Nor is it even simply a choice among alternative modes of interpreting the past. Rather, a political perspective constitutes the absolute horizon of all readings and representations of the past. The repatriation debate demonstrates that our understanding of the past is vitally dependent on our experience of the present, encompassing both situated context and political objectives, whether consciously expressed or unconsciously embedded. For within human society, there is nothing that is not social and historical, and nothing, in the final analysis, that is not political: not even the concept of time, the originary domain of the past, or the relationship of the living to the dead.

\section{Repatriation}

The issue of repatriation is rooted in the historical context of the civil rights movements of the 1960s. During this period, Native Americans, like other minority groups within the United States, gained political influence and recognition. It was within the activist climate of this era that Native peoples began to express opposition to archaeological excavations, to the public display of American Indian burials and to the permanent curation of Native American remains in museums. The differential treatment of Native burials and the seeming disregard displayed by archaeologists towards them became a powerful symbol of oppression and of the pervasiveness of racist practices for the Native community.

In 1974, the activist group American Indians Against Desecration was formed with the explicit intent of bringing political pressure to bear on the question of the return and reburial of Native American remains. Through the efforts of this group and the widespread media attention they were able to attract, the repatriation issue slowly bubbled to the surface of public consciousness and eventually captured the attention of several sympathetic law-makers. The first Federal legislation to treat this issue was the National Museum of the American Indian Act. Passed in 1989, it required the Smithsonian Institution to return all identifiable Native American remains to culturally affiliated tribal groups. The subsequent year saw passage of the Native American Graves Protection and Repatriation Act (NAGPRA), which expanded the mandate to include other categories of cultural items and all other Federally funded museums, institutions and agencies. 
The repatriation debate has often been cast in terms of science versus religion, with archaeologists situated on one side and Native peoples on the other. The central issue in this debate revolves around the question of whether $\mathrm{Na}$ tive American interests in reburying skeletal remains of ancestral populations take precedence over the interests of archaeologists and physical anthropologists in studying and preserving them. The passage of the recent legislation provides a partial answer to this question, but does not fully settle the issue. The murky language of the acts leaves several technical and philosophical questions still outstanding. I suggest these will prove equally intractable unless we are able to understand the repatriation issue in the broader sociopolitical and historical context of global de-colonization.

What we are witnessing today in the context of repatriation is a struggle to re-map the contested terrain of the past. Though typically construed as the privileged domain of archaeologists and historians, the past forms the raw material of numerous interest groups to be appropriated, preserved, exalted or denied as required in the service of contemporary goals and motivations. Within the context of repatriation, we see more clearly the many and varied stakeholders in The Past. They include physical anthropologists and Native American rights advocates, museum curators and antiquities dealers, tribal government officials and traditional religious leaders, archaeological experts and would-be researchers, government agents and nonFederally recognized tribes, pan-Indian organizations and tribal historians. Exploring the bases for the different interests in and uses of the past might suggest ways in which the construction of this antecedent temporal realm could be reconfigured as a more inclusive project.

\section{Pan-Indianism}

It was a fait accompli that we suddenly found ourselves bundled together by colonizers, and from then onwards have had to learn to ljve with each other; we who traditionally had very little in common.

MANGI 1989: 221

This remark of Jo Mangi, a Native researcher in Papua New Guinea, reflects the post-colonial condition as understood by one who has experienced modernization from the flip side.

One critique of the repatriation movement from the anthropological quarter is that the expression of generalized or pan-Indian attitudes towards the treatment of the dead and the nature of the sacred are politically motivated, with no basis in the historical 'fact' of Native American cultural diversity (cf. Mulvaney 1986). These sentiments might be seen as reflecting a neo-colonialist nostalgia for the right to reserve judgement about where history begins and ends to those sanctioned by the state to write it.

Pan-Indianism is a strategy of cultural survival. Created in the face of colonial domination by those striving to maintain their identity, pan-Indianism promotes solidarity among $\mathrm{Na}$ tive American cultures that have been brutally impacted by the relentless drive and destructive policies of the state. For communities that have experienced severe ruptures in their histories, the retrieval and reinscription of the past, no matter how fragmented, is crucial to the process of re-constituting a collective identity (Shohat 1992: 110).

The argument against pan-Indianism, taken together with the emphasis on ethnic separatism, can be construed as an effort to maintain and preserve indigenous groups in (what is given as) their 'primordial' condition. Such tactics simultaneously deny Native groups both a history and a future by inscribing the past and ensuring the atomization of class and minority interests in the present. But while the 'invented traditions' of the dominant culture may have systematically distorted the past, they have nonetheless become, in themselves, the realities through which much of the colonial encounter was and continues to be expressed (Ranger 1983). In accepting these 'imposed' traditions that advance the homogenizing efforts of the state, however, Native peoples compromise their own ability to resist domination and to renew indigenous cultural identities.

\section{The repatriation mandate}

Repatriation legislation, like other laws that treat the status of American Indians, requires an essentialized cultural entity to act and be acted upon. The Native groups recognized in this capacity by the Federal government are stable, bounded entities that are able to demonstrate some linkage to a past defined as, and forever located at, the historic moment of NativeEuroAmerican contact. It is the demonstrable relationship of continuity with this historic 
moment that confers authenticity upon contemporary Native groups. The past is thus codified in repatriation legislation as the arena in which authentic cultural identity is established and legitimated. The reification of the past as the site and source of cultural autonomy and ethnic purity is thus seen to be rooted in the politics of imperial practice.

For purposes of repatriation, the operative legal standard for the return of human remains is the concept of 'cultural affiliation', defined as 'a relationship of shared group identity that can be reasonably traced historically or prehistorically between a present day Indian tribe and an identifiable earlier group' (NAGPRA, 25 USC Section 3001, Sec. 2.(2)). Native groups wishing to reclaim cultural materials or skeletal remains are required to demonstrate the existence of such a linkage.

Ironically, repatriation legislation codifies ethnicity as an objective fact, and culture groups as discrete and timeless units, at a time when such notions are being challenged by anthropologists and Native peoples alike. Recent theories of cultural identity construe ethnicity as a subjective process in which individuals and groups identify themselves and others within the framework of specific social and political situations for specific purposes (Geary 1983: 16; Shennan 1989: 17). Cultural identities are coming to be understood less as hardened and immutable properties of individuals than as situationally constructed and fluid strategies.

Within the context of repatriation, Native American groups are forced to define and symbolize their ethnic identity in terms of categories and criteria imposed by the state. The ethnic identities constructed for American Indian groups early on by missionaries, Bureau of Indian Affairs administrators and anthropologists in many instances disregarded the complexity and fluidity of Native societies. Seeking to homogenize the confusing variety of languages, norms and cultural customs, colonial policies of the state forced the loosely structured, highly differentiated and flexible cultures of pre-conquest societies into ossified categories of 'traditions' and 'ethnic' identities. The new rigidities, immobilizations and ethnic identifications imposed and codified by the state became for EuroAmericans the fully 'traditional'. At the same time the state was defining the Native as traditional, it was creating an image of itself as modern. That Native American peoples have at different points in history attempted to repudiate these constructs is evident in the scattered pan-Indian movements that have occasionally arisen, ranging from the Ghost Dance to American Indians Against Desecration.

\section{Conclusions}

The Past has traditionally been claimed as the privileged subject of archaeology. Never innocent, the stories of The Past are constructs that serve specific agendas, whether consciously recognized or not. The particular politics of archaeology, and of science in general, involves a commitment to progress. Following Haraway (1989), archaeology might be understood as a 'fiction' appropriate to the realm of 'The Past'. Archaeology fashions facts discovered about the past into a specific narrative and produces stories about The Past that simultaneously recount and inscribe stories about relations between rich and poor, males and females, First and Third World countries, origins and the future. In the wake of decolonization, nationbuilding, civil rights struggles and ethnic pride movements, the past remains a crucially important and deeply contested myth and reality, to paraphrase Haraway (1989: 1). Archaeologists must accept that different social and intellectual histories inscribe different pasts; that other stories about the significance of the past born of other interests and motivations may be equally legitimate.

In the context of repatriation, it makes sense to question what stakes, methods, and kinds of authority are involved in oral tradition or religious accounts of the past, and how these differ from archaeological interpretation. It does not make sense 'to require a form of authority that escapes the web of the highly productive cultural fields that give rise to the accounts in the first place' (Haraway 1989: 12-13). We must acknowledge that archaeology, like all other social and natural sciences, is legitimately subject to criticism on the level of 'values', not just 'facts'. But it is recognized at the same time that this evaluation is also implicated, bound, and full of interests and stakes.

There is, of course, a legitimate concern that the new historical perspective on the significance of human remains and cultural materials is no less mythological than that of the colonial predecessors. The idea that Native 
Americans are specially qualified to understand and describe their own past contributes to a nationalistic-romantic view of Native cultures ( $c f$. Ranger 1983: 76). Rather than focusing on the idea of authentic or authorized versions of the past, different interpretations should be presented for discussion to ensure that this powerful temporal realm remains a source of inspiration and serves democratic goals.

The question, then, is not whether there is such a thing as an original and homogeneous past, and if there was, whether it would be possible to return to it. Rather, the questions must be: who is mobilizing what in the articulation of the past? what identities and representations are being deployed? what political

\section{References}

GFARY, P. 1983. Ethnic identity as a situational construct in the early middle ages, Mitteilungen der Anthropologischen Gesellschaft 113:15-26.

Goldstein, L. 1992. The potential for future relationships between archaeologists and Native Americans, in L. Wandsnider (ed.), Quandaries and quests: 59-71. Carbondale (IL): Center for Archaeological Investigations, Southern Illinois University. Occasional Paper 20.

Haraway, D. 1989. Primate visions. New York (NY): Routledge. JAMESON, F. 1981. The political unconsciousness. Ithaca (NY): Cornell University Press.

KILLION, T. \& T. BRAY. 1994. Looking toward Larsen Bay: evolving attitudes at the Smithsonian Institution, in T. Bray \& T. Killion (ed.), Reckoning with the dead: 3-9. Washington (DC.): Smithsonian Institution Press.

LORING, S. 1995. Repatriation as a guiding principle for the Arctic studies center, Anthropology Notes 17(1/2): 13-16. vision and goals are being served? Repatriation, the quest to recover the remains of the ancestors, has developed into a flexible symbol articulating widely differing points of ideological reference within the Native community. For Native cultures now in the process of forging a collective identity after having survived centuries under the brutal onslaught of colonialist regimes, the past constitutes a crucial contemporary site for this process of retrieval and reinscription, no matter how hybrid, composite or emergent that identity may be.

This paper was presented in the symposium 'The possibility of the past: contested ground in the constitution of cultural Identity' at 94th Annual Meeting of the Association of American Anthropologists, Atlanta [CA].

MaNG, J. 1989. The role of archaeology in nation building, in R. Layton (ed.), Conflict in the archaeology of living traditions: 217-27. London: Unwin Hyman.

MulvaneY, J. 1986. 'A sense of history in the making': Australian Aborigines studies 1961-1986, Australian Aboriginal Studies 2: 48-56.

RANGER, T. 1983. The invention of tradition in colonial Africa, in E. Hobsbawm \& T. Ranger (ed.), The invention of tradition: 211-62. Cambridge: Cambridge University Press.

SHOHAT, E. 1992. Notes on the post-colonial, Social Text 31/32 10(2-3): $99-113$

SHENNAN, S. 1989. Introduction: archaeological approaches to cultural identity, in S. Shennan (ed.), Archaeological approaches to cultural identity: 1-31. London: Unwin Hyman.

SPECTOR, J. 1994. Collaboration at Inyan Ceyaka Atonwan, Society for American Archaeologv Bulletin 12(3): 8-10.

\title{
Holocene humans at Pontnewydd and Cae Gronw caves
}

\section{Stephen Aldhouse-Green, Paul Pettitt \& Christopher Stringer *}

\begin{abstract}
Pontnewydd, in north Wales, is known as a rare Middle Pleistocene site in northern Europe with human remains. Radiocarbon AMS dates identify human specimens, deriving from later use of the cave at Pontnewydd and its neighbour Cae Gronw, that have no part in its earlier story.
\end{abstract}

The first well-documented examination of Pontnewydd Cave, in the Elwy Valley of northeast Wales, was conducted in the early 1870 s by McKenny Hughes \& Thomas (1874). Stone tools, recovered along with Pleistocene fauna, were compared to finds at Le Moustier and St

\footnotetext{
* S. Aldhouse-Green, Department of History \& Archaeology, University of Wales College, Newport, Caerleon Campus, PO Box 179, Newport NP6 1YG, Wales. P. Pettitt, Oxford Radiocarbon Accelerator, Research Laboratory for Archaeology and the History of Art, 6 Keble Road, Oxford ox1 3QJ, England. C. Stringer, Department of Palaeontology, Natural History Museum, Cromwell Road, London Sw7 5BD, England.
}

Received 18 December 1995, accepted 7 February 1996.

ANTIQUTYY 70 (1996): 444-7 